\title{
PENGOLAHAN PLASTIK BEKAS MENJADI BANTAL HIAS DI DESA NGEMPIT KECAMATAN KRATON KABUPATEN PASURUAN
}

\author{
Fitri Awaliyatush Sholihah ${ }^{1}$, Andi Normaladewi ${ }^{2}$, Prayitno Tri Laksono ${ }^{3}$ \\ ${ }^{1}$ Universitas Islam Malang \\ email: fitriawaliy@unisma.ac.id \\ ²Universitas Islam Malang \\ email: andinormaladewi@gmail.com \\ 3Universitas Islam Malang \\ email: mcpray_itnow@yahoo.co.id
}

\begin{abstract}
Plastic waste that can threaten the environment is increasingly overflowing in many areas. Therefore, this program is aimed to utilize waste banks by processing plastic waste into decorative pillows in Ngempit village, Kraton, Pasuruan in collaboration with the Community Information Group Surya Harapan and Etza Accesories. This program not only save the environment, but it also produces decorative pillow products which can also be a feature product of the village, so that this program indirectly can develop the creative economy of the people in Ngempit village. The method applied in this partnership program is counseling, training, demonstration and assistance. The results of the community partnership program are counseling and training on processing plastic waste into decorative pillows, counseling on marketing strategies, counseling on determination of selling price, as well as demonstration or practice of producing decorative pillow made from plastic waste with special designs, which are pictures and words in English. Finally, as a starting point, the product has been marketed at Surya Madani Business Enterprise in Ngempit village.
\end{abstract}

Keyword: processing; plastic waste; decorative pillow

\begin{abstract}
ABSTRAK
Limbah sampah plastik yang dapat mengancam lingkungan hidup semakin meluap di berbagai daerah. Oleh karena itu, program ini bertujuan untuk memanfaatkan bank sampah dengan cara mengolah plastik bekas menjadi bantal hias di desa Ngempit, kecamatan Kraton, kabupaten Pasuruan bekerja sama dengan Kelompok Informasi Masyarakat (KIM) Surya Harapan dan Etza Aksesoris. Selain menyelamatkan lingkungan hidup, program ini juga menghasilkan produk bantal hias yang sekaligus dapat menjadi produk unggulan desa, sehingga secara tidak langsung program ini dapat mengembangkan ekonomi kreatif masyarakat desa Ngempit. Metode yang diterapkan dalam program kemitraan ini adalah penyuluhan, pelatihan, demonstrasi dan pendampingan. Hasil dari program kemitraan masyarakat ini antara lain penyuluhan dan pelatihan tentang pengolahan plastik bekas menjadi bantal hias, strategi pemasaran produk dan penentuan harga jual, serta demonstrasi atau praktik pembuatan bantal hias dari plastik bekas dengan desain khusus, yaitu gambar dan tulisan berbahasa Inggris yang sebagai titik awal mulai dipasarkan di Badan Usaha Milik Surya Madani desa Ngempit.
\end{abstract}

Kata kunci : pengolahan; plastik bekas; bantal hias 


\section{PENDAHULUAN}

Meluapnya sampah plastik di berbagai daerah semakin menimbulkan kesengsaraan alam. Sampah plastik bekas makanan dan kemasan sabun merupakan sampah yang paling banyak dibuang oleh masyarakat karena mayoritas penduduk menggunakan plastik untuk kebutuhan sehari-hari, baik itu perorangan, toko, maupun perusahaan besar. Meskipun program pengurangan kantong plastik sudah lama disuarakan oleh pemerintah atau dinas terkait, masyarakat masih belum bisa lepas dari kebutuhan plastik tersebut untuk memenuhi kebutuhannya sehari-hari.

Pembuangan sampah-sampah plastik kedalam air dan tanah telah menambah tingkat kesengsaraan alam. Sampah plastik terbuat dari bahan anorganik yang sangat sulit atau bahkan tidak mungkin diuraikan oleh bakteri pengurai. Apabila ditimbun dalam tanah, untuk menguraikannya membutuhkan waktu berjuta-juta tahun, serta apabila dibakar hanya akan menjadi gumpalan dan membutuhkan waktu yang lama pula untuk mengurainya. Dan pada akhirnya, dampak terbesar limbah sampah plastik ini adalah terjadinya pemanasan global yang berdampak pada kehidupan manusia itu sendiri dan berdampak pada hewan laut yang menelan sampah plastik yang terbawa ke laut.

Fenomena ini yang menyemangati Kelompok Informasi Masyarakat (KIM) Surya Harapan di desa Ngempit, kecamatan Kraton, kabupaten Pasuruan untuk mendirikan bank sampah, sebuah wadah untuk menampung plastik bekas dari masyarakat. Program yang bertujuan untuk menyelamatkan lingkungan ini sekaligus bertujuan untuk mengembangkan ekonomi kreatif masyarakatnya. Program pengabdian berupa pelatihan pengelolaan sampah anorganik menjadi aneka kreasi daur ulang perlu terus diupayakan mengingat produksi sampah rumah tangga semakin banyak dan didukung rendahnya kesadaran 3R, yaitu reuse (memakai kembali barang bekas yang masih bisa dipakai), reduce (berusaha mengurangi sampah), dan recycle (mendaur ulang sampah agar dapat dimanfaatkan), (Suparmini, 2016).

Aktivitas pengumpulan plastik bekas dilakukan dengan cara diambil dan ditimbang oleh petugas di rumah-rumah masyarakat, kemudian dikumpulkan dan dijual ke pengepul. Sehingga hanya dengan menabung sampah plastik pada bank sampah, masyarakat bisa mendapatkan uang tambahan untuk membantu pemenuhan kebutuhan hidupnya.

Walaupun demikian, program ini dapat menjadi pasif apabila partisipasi masyarakat untuk menabung plastik bekas di bank sampah berkurang karena para tengkulak menurunkan harga belinya, sehingga harus direncanakan program yang lebih kreatif dalam mengembangkan ekonomi kreatif masyarakatnya, yaitu dengan cara memanfaatkan plastik bekas tersebut untuk diolah menjadi kerajinan tangan atau produk tertentu dengan harapan dapat meningkatkan perekonomian masyarakat. Dwiyanto (2007) menyatakan bahwa tujuan suatu system pemanfaatan sampah ialah dengan menkonversi sampah tersebut menjadi bahan yang berguna secara efisien dan ekonomis. 
Untuk mewujudkan harapan tersebut, masyarakat desa khususnya ibu rumah tangga dapat dijadikan sebagai sumber daya yang bisa memanfaatkan dan mengolah timbunan plastik bekas tersebut menjadi produk yang mempunyai nilai manfaat dan daya jual tinggi, yang tentunya dapat meningkatkan perekonomian masyarakat. Mengingat bahwa mayoritas perempuan/ibu di desa adalah ibu rumah tangga yang tidak mempunyai pekerjaan dan penghasilan. Sehingga dengan adanya bank sampah yang bisa dimanfaatkan dan diolah oleh perempuan/ibu di desa untuk dijadikan suatu produk, serta produknya dapat dijual ke masyarakat umum, tentu akan membawa dampak positif terutama dalam meningkatkan perekonomian keluarganya.

Beberapa produk kerajinan tangan yang telah dihasilkan dari pengolahan plastik bekas diantaranya adalah; tas, kalung, payung, dll. Untuk menciptakan sesuatu yang berbeda, memberikan kebermanfaatan yang lebih dan memudahkan kelompok sasaran memproduksi produk kerajinan tersebut, tim pengusul mengusulkan pengolahan plastik bekas menjadi bantal hias yang didesain khusus pada program kemitraan ini. Proses produksi ini juga melibatkan sebuah kelompok usaha kecil di desa Ngempit yaitu Etza Aksesoris. Etza aksesoris merupakan kelompok usaha kecil yang bergerak di bidang kerajinan tangan yang merupakan mitra kedua untuk membantu memberikan pendampingan dalam mengolah plastik bekas dari bank sampah binaan KIM Surya Harapan menjadi bantal hias yang didesain khusus.

Program mitra KIM Surya Harapan Ngempit dalam mengembangkan ekonomi kreatif dengan cara mengajak masyarakatnya, terutama kaum perempuan/ibu-ibu untuk menabung sampah di bank sampah merupakan program yang sangat baik dan telah berjalan dengn baik pula. Namun, untuk mencegah permasalahan atau menghadapi tantangan ke depan tentang bank sampah yang menampung plastik-plastik bekas ini, perlu direncanakan program yang lebih kreatif dan tentunya mendatangkan lebih banyak manfaat bagi masyarakat, khususnya dalam hal meningkatakan kehidupan perekonomiannya.

Keinginan dan harapan mitra KIM Surya Harapan untuk dapat mengolah sendiri limbah plastik tersebut sangat besar. Namun permasalahannya adalah mitra tidak mempunyai alat khusus untuk mengolah pastik bekas, kurangnya pengetahuan dan pengalaman dalam memanfaatkan dan mengolah plastik bekas menjadi kerajinan tangan, serta keterbatasan pengetahuan teknologi yang dimiliki oleh masyarakat. Sehingga selama ini timbunan plastik bekas hanya dapat dijualkan secara langsung kepada para tengkulak. Oleh karena itu, pembekalan pengetahuan dan pelatihan tentang memanfaatkan bank sampah dan pengolahan sampah plastik perlu diadakan. Dan salah satu cara dalam mengolah limbah plastik ini adalah dengan mengolahnya menjadi bantal hias.

Permasalahan yang kedua dialami oleh mitra kedua, Etza aksesoris. Sebagai kelompok usaha kecil yang bergerak di bidang kerajinan tangan, mitra ini cukup aktif dalam memproduksi aksesoris dan produk kerajinan tangan 
lainnya. Namun permasalahannya adalah mitra tersebut sulit untuk menentukan harga jual produk yang sesuai dengan pangsa pasar dan kurang faham tentang strategi atau manajemen pemasaran. Terbatasnya sumber daya manusia, bahan dan alat juga menjadi salah satu penghambat pada kelompok kecil ini. Sehingga kelompok kecil kreatif ini hanya berkembang di desa sekitar saja.

Berdasarkan kedua permasalahan yang telah dipaparkan, kedua mitra ini bersama dengan tim pengusul dan pelaksana bersinergi untuk merencanakan program kemitraan masyarakat pengolahan plastik bekas menjadi bantal hias. Mitra 1 sebagai pemasok bahan baku plastik bekas dan mitra 2 memberikan pendampingan pada proses produksi bantal hias.

Solusi yang ditawarkan oleh tim pengusul untuk memecahkan kedua permasalahan yang telah dipaparkan diatas adalah dengan memberikan pengetahuan, penyuluhan kepada kelompok sasaran tentang bagaimana cara mengelola bank sampah, mengolah barang-barang bekas menjadi barang yang lebih bermanfaat dan bernilai di masyarakat, Penyuluhan kepada masyarakat dilakukan untuk memberi informasi yang akurat tentang manfaat bank sampah dan mekanisme menabung dan memperoleh hasil secara sosial maupun secara ekonomis (Lestari\&Riyanto, 2018).

Program ini juga memberikan pelatihan tentang mengolah plastik bekas menjadi produk kerajinan tangan yang bernilai tinggi. Putra (2010) menyatakan bahwa keunggulan plastik dibanding material lain diantaranya kuat, ringan, fleksibel, tahan karat, tidak mudah pecah, mudah diberi warna, mudah dibentuk, serta isolator panas dan listrik yang baik. Oleh sebab itu, limbah plastik memiliki banyak keunggulan jika dapat dimanfaatkan menjadi produk daur ulang. Oleh karena itu, kegiatan utama pada program ini yaitu mengolah plastik bekas menjadi bantal hias yang dilapisi dengan sarung bantal catik yang didesain khusus dengan gambar-gambar dan tulisan berbahasa Inggris, selain sebagai sarana edukasi juga dapat menjadi ciri khas produk dari masyarakat desa Ngempit.

Selain itu, pengetahuan dan penyuluhan tentang penentuan harga produk, strategi dan manajemen pemasaran produk juga akan diberikan pada program kemitraan ini, karena diharapkan ada keberlanjutan program dari produksi bantal hias tersebut, yaitu produk bantal hias tadi dapat dijadikan produk yang dapat dijual bebas di pasaran dan dapat bersaing dengan produk UMKM lainnya. Dengan adanya penyuluhan tentang strategi pemasaran produk ini, masyarakat desa tidak akan segan untuk memasarkan produk bantal hiasnya di pasaran atau masyarakat umum, serta tidak takut bersaing dengan usaha mikro kecil menengah lainnya. 


\section{METODE PELAKSANAAN}

Berdasarkan analisis situasi yang dihadapi di lapangan tersebut, perlu adanya program yang lebih kreatif dalam memanfaatkan dan mengolah plastik bekas menjadi sebuah kerajinan tangan atau produk tertentu yang nantinya dapat digunakan sebagai lapangan pekerjaan bagi para masyarakat desa. Dengan adanya program yang lebih kreatif dalam memanfaatkan plastik bekas menjadi sebuah produk yang bernilai tinggi di masyarakat, perekonomian masyarakat akan semakin meningkat, karena produk olahan plastik bekas tersebut bernilai lebih tinggi dibandingkan dengan hanya menjual plastik bekas kepada para tengkulak.

Berkenaan dengan hal itu, untuk memberikan solusi pada permasalahan-permasalahan tersebut, langkah awal yang dilakukan dalam program kemitraan masyarakat ini adalah need analysis (analisa kebutuhan). Pengabdi bekerjasama dengan mitra mengidentifikasi beberapa hal yang harus segera dilakukan untuk merealisasikan program kemitraan masyarakat ini, yaitu antara lain; menentukan kelompok sasaran yang akan dibina, menyusun skenario pelatihan, dan mengidentifikasi peralatan yang dibutuhkan selama program kemitraan masyarakat ini berlangsung.

Berdasarkan hasil koordinasi dengan mitra, pengabdi melibatkan 20 penduduk desa berstatus ibu rumah tangga yang mempunyai bakat dan minat dalam bidang kerajinan tangan. Keduapuluh responden tersebut juga merupakan rekomendasi dari mitra KIM Surya Harapan di bidang pemberdayaan perempuan karena sebagian besar responden telah mengikuti pelatihan serupa sebelumnya, namun pengetahuan yang responden dapatkan di pelatihan sebelumnya tidak dapat teraplikasikan dengan maksimal karena beberapa hal. Pengadaan peralatan untuk menunjang kesuksesan program kemitraan masyarakat juga direalisasikan, salah satunya adalah merakit mesin pencacah plastik untuk mempermudah responden dalam memproduksi bantal hias. Selanjutnya, menentukan materi pelatihan adalah hal yang sangat penting pada program ini, dari hasil koordinasi dengan mitra. Dengan kata lain, metode utama pada pengabdian kepada masyarakat ini diantarany adalah memberikan pengetahuan dan penyuluhan tentang mengelola bank sampah, memberikan pelatihan tentang mengolah barang-barang bekas menjadi barang/produk bermanfaat dan bernilai tinggi di masayarakat, yang dikerucutkan pada pelatihan tentang pengolahan plastik bekas menjadi bantal hias yang dilapisi dengan sarung bantal berdesain khusus. Selain itu, pembekalan tentang penentuan harga jual, strategi dan manajemen pemasaran juga akan disampaikan oleh para ahli di masing-masing bidang. 


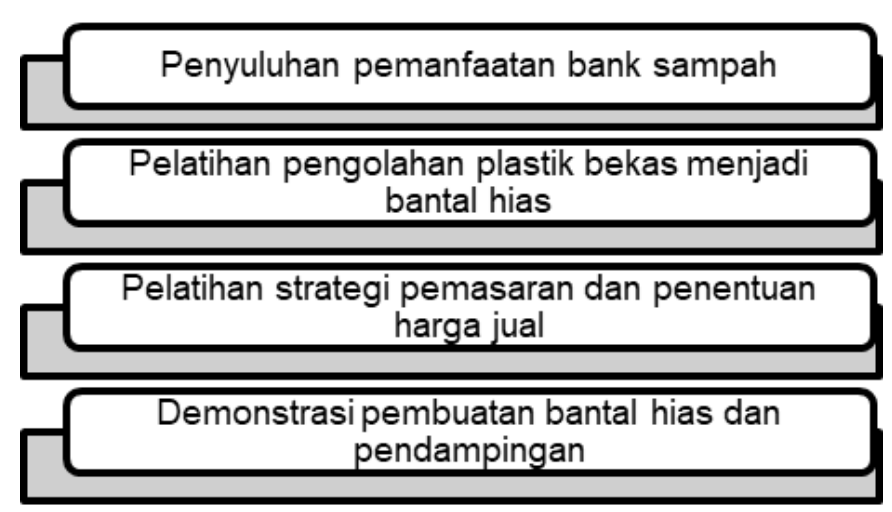

Gambar 1. Metode Program Kemitraan Masyarakat

Selain itu, untuk mengetahui tingkat kepuasan responden dan level keberhasilan terhadap program kemitraan masyarakat yang dilaksanakan, instrumen yang digunakan adalah wawancara. Wawancara semi terstuktur diajukan kepada responden, mitra, tokoh masyarakat desa, dan pihak yang telah membantu terselenggaranya program ini. Selain itu, evaluasi pada akhir kegiatan juga dilakukan untuk perbaikan program agar tujuan utama dalam program kemitraan masysrakat ini tercapai.

\section{HASIL DAN PEMBAHASAN}

Hasil dari program kemitraan masyarakat ini menunjukkan bahwa penyuluhan dan pelatihan tentang pengolahan plastik bekas menjadi bantal hias telah meningkatkan kualitas barang dari plastik bekas menjadi bantal hias. Peningkatan IPTEK juga diterapkan dalam program ini, yaitu dengan implementasi mesin pencacah plastik untuk meningkatkan kualitas plastik bekas menjadi isian dari bantal hias. Bantal hias yang diproduksi juga memberikan pengetahuan bagi masyarakat karena bantal hias tersebut didesain khusus dengan cover yang bertuliskan kosakata berbahasa Inggris.

Hasil dari program kemitraan masyarakat ini juga berkonsentrasi pada usaha industri kreatif masyarakat desa Ngempit, yaitu dengan memberikan pelatihan inovasi produk yang dijabarkan pada saat pelatihan. Penyuluhan tentang bahaya limbah plastik yang bertujuan untuk mencegah pembuangan sampah plastik dipaparkan pada program ini dengan harapan masyarakat dapat memanfaatkannya menjadi produk yang bernilai tinggi, serta penyuluhan tentang pemanfaatan plastik bekas menjadi bantal hias yang nantinya produk tersebut bisa diajdikan sebagai produk unggulan desa. Sebagai produk kreatif, karya kreasi sampah plastik memiliki nilai komersial yang menjanjikan. Produk ini memiliki daya jual yang dapat menghasilkan keuntungan bisnis kreasi sampah plastic dapat menjadi salah satu gerakan pemberdayaan komunitas di wilayah (Arico, 2017). 
Yang merupakan tujuan utama dari program kemitraan ini adalah pada aspek pemasaran produk. Kelompok sasaran telah diberikan pelatihan tentang strategi pemasaran produk handmade (bantal hias) yang bertujuan untuk memberikan pengetahuan kepada masyarakat tentang strategi memasarkan produk bantal hias ke masyarakat umum dan pelatihan tentang penentuan harga jual yang berfungsi untuk memberikan pengetahuan dan memudahkan masyarakat untuk menentukan harga jual yang sesuai dengan kualitas produk bantal hias. Berikut adalah gambaran pengolahan plastik bekas menjadi bantal hias:

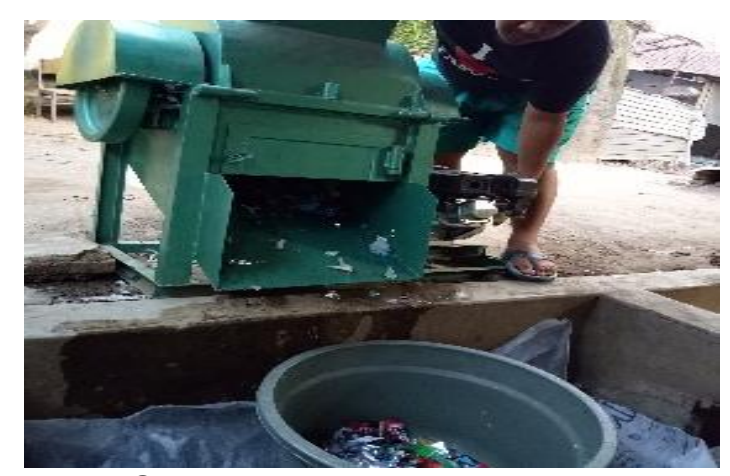

Gambar 2. Proses Pencacahan

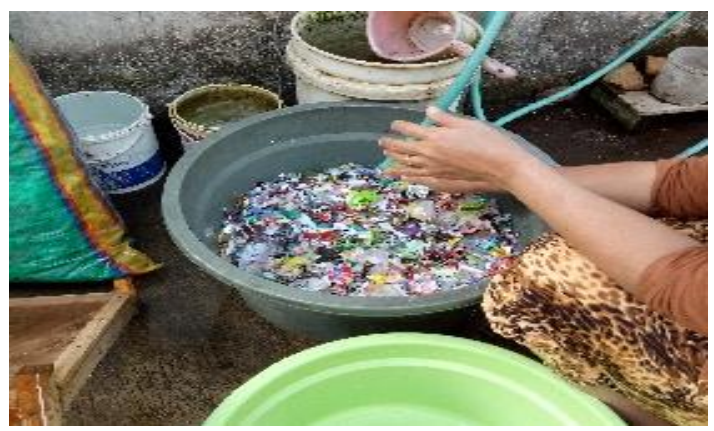

Gambar 3. Proses Pencucian

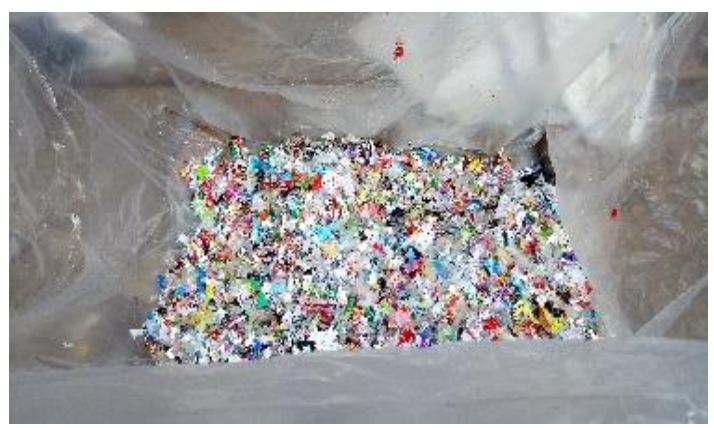

Gambar 4. Proses Pengeringan 


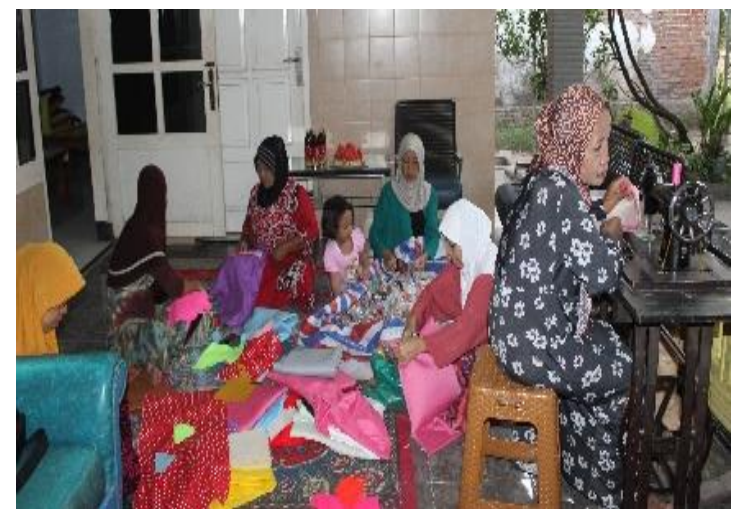

Gambar 5. Proses pembuatan bantal hias

Hasil wawancara untuk mengetahui tingkat kepuasan responden dan mengetahui level keberhasilan program juga menunjukkan respon positif. Baik responden maupun semua pihak yang terlibat pada program ini menyambut baik dan mempunyai harapan besar untuk tetap melanjutkan program ini karena produksi bantal hias cukup menarik dengan hanya bermodal pada plastik bekas yang mudah mereka dapatkan dan bahan baku lainnya yang harganya sangat terjangkau. Evaluasi untuk perbaikan program juga telah dilakukan, diantaranya adalah evaluasi terhadap proses produksi. Sampel produk bantal hias yang telah jadi dikenalkan pada masyarakat desa untuk mendapatkan kritik dan saran yang semata-mata untuk perbaikan kualitas produk bantal hias.

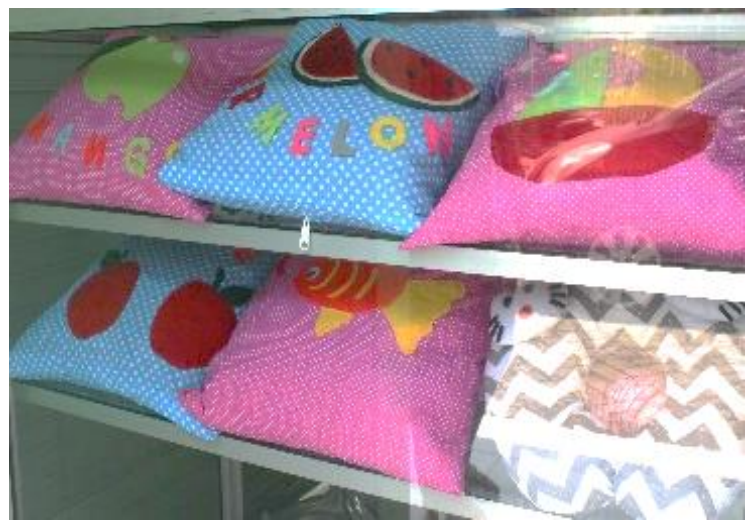

Gambar 6. Produk bantal hias

Oleh karena itu, program kemitraan masyarakat yang difokuskan pada pengolahan plastik bekas menjadi bantal hias ini nantinya diharapkan dapat menjadi lapangan pekerjaan baru bagi masyarakat desa Ngempit. Dengan pembekalan materi yang cukup tentang pemanfaatan bank sampah atau barang bekas, pengolahan plastik bekas menjadi bantal hias, penentuan harga jual produk, serta strategi dan manajemen pemasaran produk, diharapkan produksi bantal hias ini akan berlangsung secara terus menerus. Rencana 
tindak lanjut pada program kemitraan masyarakat ini adalah melakukan pendampingan dan pembekalan terhadap kestabilan ketersediaan bahan baku dan memperjelas pangsa pasar sehingga tercipta industri kreatif rumahan yang berupa produksi bantal hias, yang secara otomatis akan meningkatkan kehidupan perekonomian masyarakat desa Ngempit.

\section{KESIMPULAN}

Program Kemitraan Masyarakat tentang pemberdayaan masyarakat melalui pengolahan plastik bekas menjadi bantal hias di Desa Ngempit, Kecamatan Kraton, Kabupaten Pasuruan yang bekerjasama dengan mitra KIM Surya Harapan dan Etza Aksesoris telah berhasil meningkatkan kualitas suatu barang dan memberikan ketrampilan terhadap masyarakat desa untuk memanfaatkan barang bekas yang ada di bank sampah menjadi sesuatu yang bernilai lebih, yaitu mengolah plastik bekas menjadi bantal hias yang didesain khusus dengan gambar dan tulisan berbahasa Inggris. Program yang bertujuan untuk megembangkan ekonomi kreatif masyarakatnya ini diharapkan mampu berhasil menciptakan industri kreatif di desa Ngempit dengan cara menjadikan produk bantal hias tersebut menjadi produk unggulan desa.

Hasil yang telah dicapai dalam program ini adalah pengadaan peralatan penunjang produksi, pelatihan tentang pemanfaatan bank sampah atau barang bekas, pelatihan pengolahan plastik bekas menjadi bantal hias, penyuluhan tentang strategi pemasaran produk, penentuan harga jual produk, serta praktik produksi bantal hias. Selain itu, hasil yang telah dicapai adalah peningkatan penerapan iptek di masyarakat yaitu dengan mengaplikasikan mesin pencacah plastik, dan peningkatan nilai tambah suatu barang yaitu memanfaatkan plastik bekas menjadi bantal hias. Publikasi di media online juga telah dilaksanakan guna memberikan motivasi terhadap masyarakat untuk dapat memanfaatkan plastik bekas menjadi barang yang bernilai lebih.

\section{DAFTAR RUJUKAN}

Arico, Z (2017) Pengolahan Limbah Plastik Menjadi Produk Kreatif sebagai Peningkatan Ekonomi Masyarakat Pesisir. MARTABE Jurnal Pengabdian Masyarakat Vol 1 Nomer 1.

Dwiyanto, B.K (2007) Pencemaran Lingkungan dan Penanganannya. Yogyakarta: PT Citra Aji Parama

Lestari, N.P (2018) IbM Bank Sampah Desa Mojorejo Kota Batu. MATAPPA Jurnal Pengabdian Pada Masyarakat Vol 1 Nomer 1.

Putra, H. P \& Yebi, Y. (2010) Studi Pemanfaatan Sampah Plastik Menjadi Produk dan Jasa Kreatif. Jurnal Sains dan Teknologi Lingkungan Vol.2 No.1.

Suparmini, dkk (2016) Pelatihan Pengelolaan Sampah Anorganik Menjadi Aneka Kreasi Daur Ulang bagi Ibu Rumah Tangga dan Remaja Putri di Desa Trimulyo Kecamatan Jetis Kabupaten Bantul. Dipresentasikan pada Senaspro 2016 